\title{
User Resistance in the Implementing E-Budgeting
}

\author{
Atik Andhayani*, Sutrisno, Rosidi, Djamhuri \\ Brawijaya University \\ Malang, Indonesia \\ *atikassa75@gmail.com
}

\begin{abstract}
Local government has an essential role to play in delivering services to the city. Several local governments still have relatively low performance, particularly on the budget. There have been several barriers to the duty to introduce egovernment in local governments. Researchers see if there is a connection between e-government and users as users in terms of perceived importance and self-confidence. The study was carried out using a mix-method, both quantitative and qualitative, to ensure that it was carried out. This study contributes to the challenges of implementing e-budgeting. Resistance to the importance of user perception, self-confidence to change workers and support for leadership are required. It is hoped that the Indonesian local government will be able to enforce e-budgeting well.
\end{abstract}

Keywords—e-budgeting, resistance, implementation

\section{INTRODUCTION}

The World Bank and the UNDP have suggested that, in order to create good governance, there are three characteristics of the public sector which need to be answered, namely transparency, accountability and value for money (VfM) [1]. The idea of good governance is being searched as a solution to answer the crisis, so that it is hoped that good governance can be developed. The implementation of these concepts has various impacts, some of which assume that the concept of good governance is criticized as a colonial concept for developed countries [2], and many argue that developing countries would accept and aspire for good governance with the practice of good governance [3]

The concept offered by donor agencies is the New Public Management (NPM) paradigm which encourages performancedriven, semi-policy-driven public sector governance reforms [4]. International Financial Institutions and OECD countries could then support NPM reform in developing countries. However, many parties have argued that NPM can00000000000000not be implemented in developing countries because the system has been nepotic. According to Pillay [5], the cultural factors of each country, especially in the developing countries, will influence the implementation of the NPM, such as in the level of individualism, power distance, uncertainty, time orientation and masculinity.

Indonesia is striving to implement NPM at both the local government as well as aligning it with the regional autonomy policy beginning in 2001. NPM addresses the improvement in the quality and effectiveness of government output in public services. Even though society is already demanding the government be able to make effective use of its resources and be supported by concrete answers (outcomes), the budget must be used properly [6].

In its functionality, NPM also raises issues such as transparency, administrative autonomy and public organisations, productivity, efficiency, finance, value for money, output and market orientation, decentralization, and performance measurement and management in addition to emphasis on accounting, accrual budgeting, accounting. Costs and results-based budgeting also are central to the implementation of the NMP agenda [6].

In implementing this new paradigm, local governments are required to be able to prepare the $\mathrm{APBD}$, which becomes a measure of effectiveness in managing finances. Planning as the beginning of the process of setting organizational goals, determining strategies for achieving organizational goals, and formulating a comprehensive planning system to integrate and coordinate all work to achieve organizational goals [7]. Local government APBD according to Halim and Kusufi [8] is the starting point of work and is of concern because the budget is a tool of accountability, management and economic policy. Seeing the concept of budgeting (budgeting) as the method of compiling a financial plan, from the budget (budget) it is then allocated to each task according to the purpose and goal to be accomplished. According to Mardiasmo [9], budgeting is a phase in the preparation of the budget, while Halim and Kusufi [8] argues that the budgeting of the public sector allocates a number of funds for each program and operation in monetary units.

Local governments formulate budgets that are not according to the circumstances, according to research Indjejikian and Nanda [10] that in the performance-based budgeting process a ratchet effect appears. This effect arises when budget planners determine budget targets based on previous budget performance achievements, as a result of dynamic incentives in the context of agency relationships. Indah et al. [11] researching seven district / city local governments in Aceh found that several programs in the 2016 Education Office and Health Office were proposed solely to meet the minimum allocation quota for the health sector, 
resulting in the potential for low budget effectiveness and greater budget realization.

The government budget in Indonesia is one of the methods for assessing co-government efficiency. In order to achieve this commitment to transparency for results, the Indonesian Government supports the development of good governance through local government financial management, namely reforms to the financing system, the budgeting system, the accounting system, auditing and regional financial management systems.

Efficiency is represented in quick, open, participatory and e-government business processes [12]. The Ministry of Home Affairs has planned the implementation process of egovernment applications, from the launch in 2014 to the optimization phase in 2019. The findings show that egovernment has a favorable connection to local government efficiency, such that e-government views and audits can be used as performance measures. Local government [13]. It is hoped that the use of the system in local financial processes can reduce the corruption of local Indonesian government.

The e-budgeting framework must be enforced immediately, as local governments are expected to practice transparency in financial management, following the implementation of Government Regulation No 12 of 2019 on regional financial management. The implementation of the e-budgeting application prepared by the Ministry of Home Affairs has been incorporated, beginning with preparation (e-planning), reporting and accountability. Not all local governments in Indonesia have adopted e-budgeting until 2018.

Sulastiningsih and Alboneh [14] clarified that the causes of user resistance to the new system are conservatism, lack of direct gain, lack of management support for resource readiness, lack of organizational support and low technological efficiency. This research uses the viewpoint of the theory of technology adoption and the theory of status quo bias [15], which describes the phenomenon of user resistance in the introduction of new systems.

\section{METHODS}

Data analysis is one of the research processes that have been carried out after all the data required have been obtained to solve the problem in the report. The sharpness and precision of the use of analytical instruments decide the precision of the conclusion. Data processing operation is also a practice that can not be overlooked in the study process. Mistakes in evaluating the research method can be fatal to the conclusions that have been drawn, and this would have an even worse effect on usage and implementation.

Awareness and understanding of different analytical methods are therefore completely important for a researcher to make a significant contribution to the solution of problems through the results of his study. At the same time, these findings can be scientifically justified. Broadly speaking, data analysis strategies are divided into two sections, quantitative and qualitative. The distinction between the two strategies has to do with their data form. For qualitative data (cannot be quantitative).

In carrying out this study, the author uses a mixed method approach that incorporates quantitative and qualitative approaches. As mentioned in Creswell [16] mixed methods analysis is a research methodology that incorporates or blends both qualitative and quantitative forms. Both qualitative and quantitative methods have their respective advantages and disadvantages. Quantitative analysis is a method of testing such hypotheses by analyzing the relationship between variables. Qualitative analysis and It is hoped that the combination of these two methods would yield better results. In this research, the authors used a sequential mixed method approach, in particular a sequential explanatory approach. The sequential explanatory approach is a mixed-method analysis that appears to be more quantitative. A sequential explanatory approach is used to collect quantitative data analysis data at the first level, followed by qualitative data collection and analysis at the second point.

The following is an outline of the flow of analysis. Based on the characteristics of the sequential explanatory combination process, the study uses quantitative methods in the first stage and qualitative methods in the second stage. Thus, combined research is carried out to respond to quantitative research problem formulations and qualitative problem formulations, or to separate yet complementary problem formulations. Researchers shall take the quantitative analysis procedures as follows: 1. Identifying problems / potentials and formulating problems. 2. Conducting analytical experiments and constructing theories. 3. Collect and interpret the data for the test of hypotheses. 4. Make assumptions based on the findings of the test hypotheses. Take the qualitative analysis protocol as follows: 1. Determine the source of the data for analysis. 2 . Collect and analyze the quality data. 3. Analyze quantitative and qualitative data 4 . Provide $\mathrm{c}$ to.

The population of this study was all users of e-budgeting in the Government of East Java. Samples were obtained from 69 e-budget users in 3 sub-districts of the Batu City Government. The sample is part of the number and characteristics of the population that the researcher considers to be representative of the target population. For this reason, the sample is taken from a portion of the population number and characteristics of the population on its own, does not take the entire to be analyzed and is assumed to be representative of the target population. The characteristics of the sample are calculated objectively by the researcher in order to satisfy the data needs in the field, the characteristics themselves serve as a form of identification for respondents in the provision of data, including: education, age, and the key tasks and functions (tupoksi) of e-budget users.

\section{RESULTS}

The budget has several functions, namely as a planning tool, a control tool, a fiscal policy tool, a political tool, a coordination and communication tool, a performance appraisal 
tool as well as a motivational tool [17]. The budget as a performance appraisal tool is assessed based on the determination of the budget and targets that are achieved. Performance-based budgeting is the answer as a more efficient and effective means of measuring and accounting for government performance.

Performance-based budgeting is a method of budgeting for management to link any funding poured into activities with outputs and expected outcomes including efficiency in achieving the results of these outputs. The outputs and results are set forth in the performance targets for each work unit, while how these goals are achieved are outlined in programs followed by financing at each level of achieving the goals.

To date, the formulation and application of the APBD has faced several hurdles in the local government of Indonesia. Research on the problems of the APBD in the Bolaang Mongondow Regency Government of North Sulawesi, according to Paputungan et al. [18], planning via the programs and activities of the Regional Work Units (SKPD) has not earned an assurance that there will be no cuts in the budget allocations for new e-planning in 2017. Study in the SarmiPapua district of the Government has experienced delays to.

The Wonosobo District Government is late in compiling the 2009-2012 APBD, according to Van Meter and Van Horn [19] other studies it is also due to lack of education and training related to regional financial budgeting; not yet effective and productive performance of the regional apparatus; power of the regional chief. The consequence of the delay in the preparation of the APBD is the delay in the implementation of local government programs affecting public services.

Budget issues related to authoritative culture are still an inseparable part of public services, bureaucrats still place their interests ahead of public interests. Local governments have not implemented democratic and participatory management and administration that emphasizes the interests of public satisfaction as well. APBD budgeting is closely related to performance accountability in terms of public satisfaction with public services and is a crucial issue for local governments as the closest strata of society in Indonesia.

The government considers e-governmet to be relevant and encourages all local governments in Indonesia to implement ebudgeting. In practice, while East Java is the leader of the new method, it has not been applied equally in all regional governments. The following is the incorporation of e-planning and e-budgeting in the East Java Regional Government. East Java was the initiator of e-government and the initiator of the concept of introducing e-budgeting from 2015 to 2019.
TABLE I. INTEGRATION OF E-PLANNING AND E-BUDGETING LOCAL GOVERNMENT IN EAST JAVA

\begin{tabular}{|l|l|l|l|}
\hline Year & $\begin{array}{c}\text { Number of Local } \\
\text { Governments }\end{array}$ & $\begin{array}{c}\text { Not Yet } \\
\text { Implemented }\end{array}$ & Implemented \\
\hline 2015 & 38 & 36 & 2 \\
\hline 2016 & 38 & 34 & 4 \\
\hline 2017 & 38 & 24 & 10 \\
\hline 2018 & 38 & 20 & 14 \\
\hline 2019 & 38 & 20 & 14 \\
\hline
\end{tabular}

Data: processed

Get more complete information on user concerns in the implementation of e-budgeting in East Java. A questionnaire was then administered in three sub-districts of the Batu City Government. Due to restricted time and conditions, the following reports have been obtained.

TABLE II. THE QUESTIONNAIRE WAS CONDUCTED IN 3 DistRICT GOVERNMENT OF BATU CITY USER RESISTANCE IN THE IMPLEMENTATION OF E-BUDGETING

\begin{tabular}{|l|l|}
\hline No & \multicolumn{1}{c|}{ Information } \\
\hline 1 & User perceptions have not been equated \\
\hline 2 & Still lacking confidence in implementation \\
\hline 3 & Inadequate infrastructure \\
\hline 4 & Commitment of policy makers \\
\hline 5 & OPD Support (Head and all staff) \\
\hline 6 & Technology is not yet supported \\
\hline 7 & Human Resources who implement \\
\hline
\end{tabular}

Data: processed

It is understood from the above data that user resistance is induced in the implementation of e-budgeting. These things include User perceptions have not been equated still lacking confidence in implementation, inadequate infrastructure, commitment of policy makers, OPD Support (head and all staff), technology is not yet supported, and human resources who implement.

\section{CONCLUSION}

According to Usui and Alisjahbana [20], while some $60 \%$ of local governments have shifted to a modern budget format since 2003, the idea of strategic multi-year planning and performance-based budgeting is not well understood by local governments. The performance-based budgeting format prepared by the regional government still has several drawbacks due to several factors, namely the lack of an approximate goal, a poor relation between the development plan and the relation between the development plan. Budget issues related to authoritative culture remain an inseparable part of public services, although bureaucrats also put their interests ahead of the public interest. Local governments have not adopted democratic and participatory governance and administration that also stresses public satisfaction. APBD budgeting is closely linked to performance transparency in terms of public satisfaction with public services and is a critical concern for local governments as the most closely related concern. Resistance to the importance of user perception, selfconfidence to change workers and support for leadership are required. 


\section{REFERENCES}

[1] K.Q.I. Elahi, "UNDP on Good Governance." International Journal of Social Economics,vol. 36, no. 12, pp. 13, 2009.

[2] A. Farazmand, Sound Governance Policy and Administrative Innovations. 1 ed. London: Praeger Publishers, 2004, pp. 330.

[3] R.L. Holzhacker, R. Wittek, and J. Woltjer, Introduction Decentralization and Governance in Indonesia. Yilin Hou S, USA, editor. New York: Springer International Publishing Switzerland, 2015, p. 43.

[4] C. Hood, The "New Public Management" In The 1980s: Variations On A Theme. Acounting Organization and Society, Vol. 20, No.2/3, pp. 16, 1995.

[5] S. Pillay, "A Cultural Ecology Of New Public Management," International Review of Administrative Sciences, Vol. 74, No. 3, pp. 373-94, 2008.

[6] E. Anessi-Pessina, B. Carmela, S. Mariafrancesca, and I. Steccolini, "Public Sector Budgeting: A European Review Of Accounting And Public-Management Journals," Accounting, Auditing and Accountability Journal, Vol. 29, No. 3, pp. 37, 2016.

[7] I. Bastian, Akuntansi Sektor Publik Suatu Pengantar 3ed. Jakarta: Erlangga, 2010.

[8] A. Halim and M.S. Kusufi, Teori, Konsep, dan Aplikasi Akuntansi Sektor Publik. Jakarta: Salemba Empat, 2014.

[9] Mardiasmo, Akuntansi Sektor Publik. Yogyakarta: ANDI, 2009.

[10] R. Indjejikian and D. Nanda, "Dynamic Incentives and Responsibility Accounting," Journal of Accounting and Economics, Vol. 27, pp. 37, 1998.

[11] D.R. Indah, S. Abdullah, A. Junita, and H. Fahlevi, "Kajian Kepatuhan Pemerintah Daerah atas Peraturan Perundang-undangan dalam Pengelolaan Keuangan Daerah di Aceh (Studi Kasus pada Dinas
Kesehatan)," Jurnal Manajemen dan Keuangan, Vol. 6, No. 1, pp. $627-$ 37, 2017.

[12] KemenPANRB, Laporan Kinerja Kementerian PANRB 2018. Jakarta: Kementerian Pendayagunaan Aparatur Negara Dan Reformasi Birokrasi, 2019.

[13] B. Sutopo, T.R. Wulandari, A.K. Adiati, and D.A. Saputra, "EGovernment, Audit Opinion, And Performance Of Local Government Administration In Indonesia," Australasian Accounting, Business Finance Journal, Vol. 11, No. 4, pp. 6-22, 2017.

[14] S. Sulastiningsih and Z. Alboneh, "Pengaruh Karakteristik Tujuan Anggaran Terhadap Akuntabilitas Kinerja Instansi Pemerintah Daerah Kabupaten Sleman," vol. 7, no. 2, pp. 113-28, 2020.

[15] W. Samuelson and R. Zeckhauser, "Status Quo Bias in Decision Making" Journal of Risk and Uncertainty, Vol. 1, p. 53, 1988.

[16] J.W. Creswell, A Concise Introduction to Mixed Methods Research: SAGE publications, 2014.

[17] R. Rubenstein, "Budgeting and Fiscal Management," Journal International Training Program, GSU, Atlanta, 2002.

[18] A. Paputungan, V. Ilat, and J. Morasa, "Analisis Proses Perencanaan dan Penganggaran APBD (Studi Kasus pada Pemerintah Kabupaten Bolaang Mongondow)," Jurnal Riset Akuntansi Dan Auditing" Goodwill", Vol. 8, No. 1, 2017.

[19] D.S. Van Meter and C.E. Van Horn, "The Policy Implementation Process: A Conceptual Framework," J Administration Society, Vol. 6, No. 4, pp. 445-88, 1975.

[20] N. Usui and A. Alisjahbana, Local Development Planning And Budgeting In Decentralized Indonesia: Update. International Symposium On Indonesia's Decentralization Policy: Problems And Policy Directions; September 4-5, 2003; Shangri-La Hotel, Jakarta, Indonesia2003. p. 36. 